\title{
Correction to: The diachronic threshold problem
}

\author{
Rodrigo Borges ${ }^{1}$
}

Published online: 11 November 2021

(c) Springer Nature B.V. 2021

\section{Correction to: Philos Stud https://doi.org/10.1007/s11098-021-01652-x}

In the original publication of the article, the article title was published identical to another publication in the same journal. Author has now changed the title to "The Diachronic Threshold Problem”. The original article has been corrected.

Publisher's Note Springer Nature remains neutral with regard to jurisdictional claims in published maps and institutional affiliations.

The original article can be found online at https://doi.org/10.1007/s11098-021-01652-x.

Rodrigo Borges

epistemen@icloud.com

1 University of Florida, Gainesville, USA 